\title{
Magnesium and Micro-Elements in Older Persons
}

\author{
Nicola Veronese * and Mario Barbagallo (D) \\ Geriatrics Section, Department of Internal Medicine, University of Palermo, 90127 Palermo, Italy; \\ mario.barbagallo@unipa.it \\ * Correspondence: nicola.veronese@unipa.it
}

Citation: Veronese, N.; Barbagallo, M. Magnesium and Micro-Elements in Older Persons. Nutrients 2021, 13, 847. https://doi.org/10.3390/ nu13030847

Received: 20 February 2021

Accepted: 3 March 2021

Published: 5 March 2021

Publisher's Note: MDPI stays neutral with regard to jurisdictional claims in published maps and institutional affiliations.

Copyright: (c) 2021 by the authors. Licensee MDPI, Basel, Switzerland. This article is an open access article distributed under the terms and conditions of the Creative Commons Attribution (CC BY) license (https:// creativecommons.org/licenses/by/ $4.0 /)$.
Macro- and micro-element deficiencies are widely diffused in older people. The deficiency of these elements in older people is often attributable to malnutrition, even if other medical conditions (such as gastrointestinal problem) or non-medical conditions (such as polypharmacy) can lead to these deficiencies [1]. It is estimated that malnutrition is present in $1.3-47.8 \%$ of older people living in the community, being higher in other settings and in low-middle income countries [2].

Malnutrition is often followed by deficiency in both macro-elements (i.e., minerals with a requested amount of at least $100 \mathrm{mg}$, e.g., calcium (Ca), sodium ( $\mathrm{Na}$ ) or Magnesium (Mg) and micro-elements ( $<100 \mathrm{mg} /$ day, such as iron (Fe), Zinc (Zn) or Selenio (Se). Moreover, the scarcity of trace elements, such as Chromium (Cr+++), Silicium (Si), or Vanadium (V), could be present in malnourished older people.

At the same time, for several years, it was assumed that malabsorption of both macroand micro-elements was a common problem among older people [3], but increasing literature has suggested that it is not ever true, since older persons who malabsorb macronutrients often do so because of a disease (such as cancer or gastrointestinal problems), not because of age itself [3].

From an epidemiological point of view, the limited introduction of macro- and microelements is traditionally associated with a wide spectrum of medical conditions common in geriatric medicine, especially metabolic and cardiovascular diseases [4], dementia [5], frailty [6], sarcopenia [7] and, finally, mortality [8].

For these reasons, in this Special Issue entitled Magnesium and Micro-Elements in Older Persons and published in Nutrients, we decided to report the state-of-the-art regarding the deficiency of both $\mathrm{Mg}$ and micro-elements and the consequences in terms of higher risk of certain diseases in geriatric medicine.

In particular, the interest in $\mathrm{Mg}$ is due to several reasons. First, $\mathrm{Mg}$ is sometimes defined as "the forgotten electrolyte" [9], since it is less frequently required in our patients than other similar elements. Despite this, as also shown in our Special Issue, poor Mg status is associated with several negative outcomes in older people. For example, novel data on $\mathrm{Mg}$ and dementia in more than 10,000 older participants followed-up for about 25 years were reported, showing that low midlife serum $\mathrm{Mg}$ is associated with increased risk of incident dementia, independently from several confounder factors [10]. Other authors have explored the importance to supplement $\mathrm{Mg}$ for increasing vitamin D levels in postmenopausal women [11] and for improving several cardiovascular biomarkers [12]. These novel findings could partly explain the role of $\mathrm{Mg}$ in improving outcomes in infectious diseases [13] and for improving hypertension [14], one of the most common condition in older subjects, as discussed in two reviews. Furthermore, the correct assessment of $\mathrm{Mg}$ status, particularly in older people, is often problematic. Serum $\mathrm{Mg}$, in fact, could be not considered as a good proxy of $\mathrm{Mg}$ deposits in human bodies, since it is poorly correlating with intracellular $\mathrm{Mg}$ [15]. Other laboratory assessments are expensive and difficult to realize in daily clinical practice, particularly in older subjects [16]. It is important to note that about $2 / 3$ of older people did not consume enough amounts of this micronutrient [17] 
and as previously mentioned, $\mathrm{Mg}$ deficiency is associated with several conditions in geriatric medicine.

In our Special Issue, we have also collected data regarding micro-elements. In our opinion, this aspect better completes the scenario of poor nutritional status in older people. Cardiovascular aspects are also covered by a systematic review that shows the importance of low sodium intake and a high potassium/sodium intake for preventing cardiovascular conditions in older people [18]. These topics are of critical importance since cardiovascular diseases are the leading cause of mortality in aged people. Furthermore, our Special Issue is completed by other studies regarding the importance of some micro-elements in sarcopenia, such as omega-3 fatty acids, and vitamins D, A, and K [19]. Finally, an interesting Review regarding iron metabolism is presented [20]. Iron deposits, in fact, can contribute to the development of inflammation, abnormal protein aggregation, and degeneration in the central nervous system that may increase the risk of several neurological disorders such as multiple sclerosis, Parkinson's disease, Alzheimer's disease, or stroke [20].

We hope that with this Special Issue the Reader can better understand the importance of $\mathrm{Mg}$ and micro-elements in healthy aging and in some medical conditions in older people, further highlighting the impelling necessity to frequently monitor the nutritional status of aged subjects, a topic often forgotten in actual geriatric medicine.

Author Contributions: Writing—original draft preparation, N.V.; writing-review and editing, M.B. All authors have read and agreed to the published version of the manuscript.

Funding: This research received no external funding.

Institutional Review Board Statement: Not applicable.

Informed Consent Statement: Not applicable.

Data Availability Statement: Not applicable.

Conflicts of Interest: The authors declare no conflict of interest.

\section{References}

1. Guyonnet, S.; Rolland, Y. Screening for malnutrition in older people. Clin. Geriatr. Med. 2015, 31, 429-437. [CrossRef] [PubMed]

2. World Health Organization. Integrated Care for Older People: Guidelines on Community-Level Interventions to Manage Declines in Intrinsic Capacity; World Health Organization: Geneva, Switzerland, 2017.

3. Russell, R.M. Factors in aging that effect the bioavailability of nutrients. J. Nutr. 2001, 131, 1359S-1361S. [CrossRef] [PubMed]

4. Tang, Y.-R.; Zhang, S.-Q.; Xiong, Y.; Zhao, Y.; Fu, H.; Zhang, H.-P.; Xiong, K.-M. Studies of five microelement contents in human serum, hair, and fingernails correlated with aged hypertension and coronary heart disease. Biol. Trace Elem. Res. 2003, 92, 97-103. [CrossRef]

5. Kieboom, B.C.; Licher, S.; Wolters, F.J.; Ikram, M.K.; Hoorn, E.J.; Zietse, R.; Stricker, B.H.; Ikram, M.A. Serum magnesium is associated with the risk of dementia. Neurology 2017, 89, 1716-1722. [CrossRef] [PubMed]

6. Gimeno-Mallench, L.; Sanchez-Morate, E.; Parejo-Pedrajas, S.; Mas-Bargues, C.; Inglés, M.; Sanz-Ros, J.; Román-Domínguez, A.; Olaso, G.; Stromsnes, K.; Gambini, J. The Relationship between Diet and Frailty in Aging. Endocr. Metab. Immune Disord. Drug Targets (Former. Curr. Drug Targets Immun. Metab. Disord.) 2020, 20, 1373-1382. [CrossRef] [PubMed]

7. Giglio, J.; Kamimura, M.A.; Lamarca, F.; Rodrigues, J.; Santin, F.; Avesani, C.M. Association of sarcopenia with nutritional parameters, quality of life, hospitalization, and mortality rates of elderly patients on hemodialysis. J. Ren. Nutr. 2018, 28, 197-207. [CrossRef] [PubMed]

8. Black, R. Micronutrient Deficiency: An Underlying Cause of Morbidity and Mortality; SciELO Public Health: Baltimore, MA, USA, 2003.

9. Ahmed, F.; Mohammed, A. Magnesium: The forgotten electrolyte-A review on hypomagnesemia. Med. Sci. 2019, 7, 56. [CrossRef] [PubMed]

10. Alam, A.B.; Lutsey, P.L.; Gottesman, R.F.; Tin, A.; Alonso, A. Low serum magnesium is associated with incident dementia in the ARIC-NCS cohort. Nutrients 2020, 12, 3074. [CrossRef]

11. Vázquez-Lorente, H.; Herrera-Quintana, L.; Molina-López, J.; Gamarra-Morales, Y.; López-González, B.; Miralles-Adell, C.; Planells, E. Response of vitamin D after magnesium intervention in a postmenopausal population from the province of Granada, Spain. Nutrients 2020, 12, 2283. [CrossRef] [PubMed]

12. Alonso, A.; Chen, L.Y.; Rudser, K.D.; Norby, F.L.; Rooney, M.R.; Lutsey, P.L. Effect of magnesium supplementation on circulating biomarkers of cardiovascular disease. Nutrients 2020, 12, 1697. [CrossRef] [PubMed]

13. Dominguez, L.J.; Veronese, N.; Guerrero-Romero, F.; Barbagallo, M. Magnesium in Infectious Diseases in Older People. Nutrients 2021, 13, 180. [CrossRef] [PubMed] 
14. Dominguez, L.; Veronese, N.; Barbagallo, M. Magnesium and Hypertension in Old Age. Nutrients 2021, 13, 139. [CrossRef] [PubMed]

15. Veronese, N.; Zanforlini, B.M.; Manzato, E.; Sergi, G. Magnesium and healthy aging. Magnes. Res. 2015, 28, 112-115. [CrossRef] [PubMed]

16. Barbagallo, M.; Belvedere, M.; Dominguez, L.J. Magnesium homeostasis and aging. Magnes. Res. 2009, 22, 235-246. [CrossRef] [PubMed]

17. Wood, R.J.; Suter, P.M.; Russell, R.M. Mineral requirements of elderly people. Am. J. Clin. Nutr. 1995, 62, 493-505. [CrossRef] [PubMed]

18. Gonçalves, C.; Abreu, S. Sodium and Potassium Intake and Cardiovascular Disease in Older People: A Systematic Review. Nutrients 2020, 12, 3447. [CrossRef]

19. Lengelé, L.; Moehlinger, P.; Bruyère, O.; Locquet, M.; Reginster, J.-Y.; Beaudart, C. Association between Changes in Nutrient Intake and Changes in Muscle Strength and Physical Performance in the SarcoPhAge Cohort. Nutrients 2020, 12, 3485. [CrossRef] [PubMed]

20. Grubić Kezele, T.; Ćurko-Cofek, B. Age-Related Changes and Sex-Related Differences in Brain Iron Metabolism. Nutrients 2020, 12, 2601. [CrossRef] [PubMed] 